\begin{tabular}{|l|c|c|}
\hline \multicolumn{2}{|c|}{ DJS Vol. 38 (2017) 260-274 } \\
\hline Research Article & Delta Journal of Science & \\
\hline https://djs.journals.ekb.eg/ & Available online at \\
\hline
\end{tabular}

\title{
Impact of nano calcium hydroxide and calcium oxide on some metabolic activities and phenolic compounds of Lupinus termis seedlings \\ Awatif A. Mohsen $^{(1)}$, M. El-Kemary(2), Samha M.A. Dowidar ${ }^{(1)}$, Shaimaa A. Abo-Hamad ${ }^{(1)}$, M. A. \\ Elhaak $^{(1)}$, Basma M. M. Khalaf ${ }^{(1)}$ \\ (1) - Botany Department Faculty of Science, Tanta University \\ 2) - Chemistry Department, Faculty of Science, Kaferelsheikh University
}

Abstract The effect of $0.5,1.0$ and $2.0 \mathrm{mM}$ nano calcium hydroxide $\mathrm{Ca}(\mathrm{OH})_{2}$ and calcium oxide $\mathrm{CaO}$ or bulk calcium carbonate $\mathrm{CaCO}_{3}$ on growth and metabolic changes of Lupines termis seedlings was assessed. Root fresh and dry weights were increased by nano $\mathrm{CaO}$ at 0.5 and $1.0 \mathrm{mM}$ compared with the control, while they were decreased by increasing nano $\mathrm{Ca}(\mathrm{OH})_{2}$. Shoot fresh and dry weights were increased by increasing the concentration of nano $\mathrm{Ca}(\mathrm{OH})_{2}$ and $\mathrm{CaO}$ reaching their maximum at 0.5 and $2.0 \mathrm{mM}$, respectively. Bulk $\mathrm{CaCO}_{3}$ concentrations increased root and shoot fresh and dry weights at the highest concentration $(2 \mathrm{mM})$. The photosynthetic pigments (chl.a, chl.b and carotenoids) were markedly increased with increasing the concentration of nano $\mathrm{Ca}(\mathrm{OH})_{2}$, nano $\mathrm{CaO}$ and bulk $\mathrm{CaCO}_{3}$ with the highest magnitude recorded for nano $\mathrm{Ca}(\mathrm{OH})_{2}$, while the lowest was for $\mathrm{CaCO}_{3}$. The total soluble carbohydrate biosynthesis of both shoot and root was reduced by nano calcium particles, whereas it was enhanced by bulk calcium compared with control. The root soluble protein was decreased by different concentrations of either nano or bulk calcium, while shoot soluble protein was increased by all calcium treatments compared with the control. The nano calcium especially $\mathrm{Ca}(\mathrm{OH})_{2}$ activated the protein metabolism compared with the bulk. The root and shoot phenolic compounds were decreased by different concentrations of either nano or bulk calcium, except of the shoot phenolic compounds at $\mathrm{CaCO}_{3}$. Nano $\mathrm{CaO}$ at $0.5 \mathrm{mM}$ increased shoot phenolic compounds by $10 \%$ compared with control.

Keywords: Lupinus termis, Nano calcium, Bulk calcium, Photosynthetic pigment, Growth criteria, Carbohydrates, Protein, Phenolic compounds.

\section{INTRODUCTION}

Lupinus termis (Lupin) plant is an herbaceous perennial plant belonging to the order fabales, family
Fabaceae, subfamily papilionoideae (EFSA, 2005). The plant root is a normal tap root. The plant has a simple raceme inflorescence which produces as many as 70 
flowers on the main stem. The flowers open in ascending order into cream orbicular or flattened shape pod.

The genus lupinus includes over 450 species worldwide (EFSA, 2005) but only the following four major cultivated species have gained agricultural importance viz., white lupin (Lupinus albus L.), blue lupin (L. angustifolius L.), yellow lupin (L. luteus L.) of the "Old World" or Mediterranean area lupin species and one "New World" species namely Andean lupin (L. mutabilis L.). Both of the last species have wild forms and cultivated crops (Gladstones, 1998; Erbas et al., 2005) in Mediterranean region, Sudan, Ethiopia, Central and Western Europe, Australia, USA and South America, Tropical and Southern Africa, Russia, and Ukraine (Kwak et al., 2000; Kettel et al., 2003).

Plant seeds are high in protein, lipids, dietary fiber, carbohydrates and calcium (Gabrial and Morcos, 1976; Petterson, 1998 and Bhardwaj et al., 2010). Lupin (quinolizidine alkaloid) is responsible for bitter taste and neurotoxins (Yeheyis et al., 2011). The major Lupinus albus seed alkaloids are Lupanine (Huyghe, 1997; Olver, 1998; Getachew, 2009), hydroxyaphylline, albine, multiflorine (Getachew, 2009), anagraine (Yildiz, 2011) and sparteine (Huyghe, 1997; Erbas et al., 2005).

Lupin has food applications, particularly as desirable additives in bakery and pasts products, or as meat, egg and milk replacers, traditional and alcohol production, snack as well as in dietary and functional food products (Loza and Lampart- Szczapa, 2008). Lupin protein with fibers lowers serum cholesterol level, improves glucose tolerance and consequently modifies blood insulin and glucagon (Chango et al., 1998). The seeds are used as carminative, diuretic, emmenagogue, hypoglycemic, pectoral and vermifuge and are used as well as a poultice on ulcers. (Chiej, 1984).

The field of nanotechnology is one of the most active areas of research in modern material science. Nanoparticles exhibit completely new or improved properties based on their specific characteristics such as size, distribution and morphology affecting their physical and chemical characteristics. Nanoparticles (NPs) or (Nano scale particles $=$ NSPs) are defined as ultrafine particles with lengths in two or three dimensions greater than $1 \mathrm{~nm}$ and smaller than $100 \mathrm{~nm}$ (ASTM, 2006). The physical and chemical properties of nanoparticles can differ significantly from those of bulk materials of the same composition. Due to NPs unique physical and chemical characteristics, recently they are widely used in many areas such as industry, agriculture, business, medicine, public health among many other (Rao and Shekhawat, 2014).

Ruffini-Castiglione and Cremonini (2009) have identified three types of NSPs: natural, incidental and engineered (can be carbon-based or metal based materials (Peralta-Videa et al., 2011). Metal oxide is one of the metal- based groups. Metal oxide nanoparticles such as $\mathrm{Ca}(\mathrm{OH})_{2}$ or $\mathrm{CaO}$ are important materials due to their widespread applications in various aspects including catalysis, sensors, optoelectronic materials, and environmental remediation (Oskam ,2006).

Calcium is the fifth most abundant element (by mass), usually found in sedimentary rocks in the mineral forms of calcite, dolomite and gypsum. It is one of the main macro essential nutrients for plant growth and development; formation of cellular walls, enzyme activators, metabolic processes, nitrate uptake, biomass accumulation (Savithramma, 2002) and photosynthetic rate (Savithramma, 2004; Savithramma et al., 2007).

The aim of this study is to evaluate the effect of both nano calcium hydroxide and calcium oxide as well as bulk calcium on the growth and some metabolic activities of Lupinus termis

\section{MATERIALS AND METHODS}

Synthesis of calcium oxide and calcium hydroxide nanoparticles

Calcium oxide $(\mathrm{CaO})$ nanoparticles were prepared by calcination of $\mathrm{Ca}(\mathrm{OH})_{2}$ which was synthesized by adding $\mathrm{NaOH}$ solution to $\mathrm{CaCl}_{2} \cdot 2 \mathrm{H}_{2} \mathrm{O}$ solution without using any surfactant, organic medium 
and complicated tools (Mirghiasi et al., 2014), according to the reactions illustrated in equations. (1)

and (2).

$$
\begin{aligned}
& \mathrm{CaCl}_{2}+2 \mathrm{NaOH} \rightarrow \mathrm{Ca}(\mathrm{OH})_{2}+2 \mathrm{NaCl} \\
& \mathrm{Ca}(\mathrm{OH})_{2} \stackrel{\text { Calcination }}{\longrightarrow} \mathrm{CaO}+\mathrm{H}_{2} \mathrm{O}
\end{aligned}
$$

This method can be used as a simple, cheap and convenient way for producing calcium oxide and hydroxide nanoparticles on a large industrial scale.

\section{Characterization of nano calcium}

\section{XRD Analysis}

The crystalline structure of $\mathrm{Ca}(\mathrm{OH})_{2}$ and $\mathrm{CaO}$ nanoparticles was characterized by X-ray diffraction (XRD, Shimadzu 6000 system, $\lambda=1.54 \mathrm{~A}^{\circ}$ ).

\section{TGA Analysis}

Thermal behavior for the precursor was studied through thermogravimetric analysis (TGA), which was performed with a Shimadzu DTA- SO under nitrogen flow.

\section{TEM Analysis}

The morphology and average particle size of nano-particles were further investigated by a transmission electron microscope (TEM) (JEOL- Jem2100).

\section{Plant materials}

The experimental plant used in the present investigation was Lupinus termis (Lupinus) cv. Giza 1. Seeds were obtained from the Egyptian Ministry of Agriculture, Giza, Egypt.

\section{Experimental Design:}

During the growth season (November and December, 2014), a fixed number of Lupinus termis seeds were sterilised by $0.01 \% \mathrm{HgCl}_{2}$ for one $\mathrm{min}$, washed thoroughly with distilled water and divided into four groups. Each group was sown in plastic pots (15 cm diameter and $10 \mathrm{~cm}$ depth) filled with $5 \mathrm{~kg}$ clay-sandy soil $(2: 1 \mathrm{w} / \mathrm{w})$ and 5 pots were used for each treatment. The first group of seeds was sown in untreated soil representing the control. The second one was sown in soil supplemented with different nano calcium hydroxide $\left[\mathrm{Ca}(\mathrm{OH})_{2}\right]$ concentrations $(0.5,1.0$ and $2 \mathrm{mM}$ ). The third group was sown in soil provided with different nano calcium oxide $(\mathrm{CaO})$ concentrations $(0.5,1$ and $2 \mathrm{mM})$ and the seeds of the fourth one were sown in a soil supplemented with different calcium carbonate concentrations $(0.5,1.0$ and $2 \mathrm{mM}$ ) and was considered as bulk $\mathrm{CaCO}_{3}$. The seeds were left to germinated and grow as the usual practice and irrigated firstly with different concentrations of all calcium treatments to field capacity then irrigated with distilled water under greenhouse conditions. After 15 days of growth the seedlings were executed, washed with distilled water then separated into root and shoot. The growth criteria as lengths, fresh and dry weights of root and shoot were measured. Samples of three fresh leaves were kept frozen immediately for determination of the photosynthetic pigments. The remaining samples were dried in an oven at $60^{\circ} \mathrm{C}$ for determination of metabolic constituents.

\section{Estimation of Photosynthetic Pigments:}

The plant photosynthetic pigments (chlorophyll a, chlorophyll b, and carotenoids) were determined spectrophotometrically as recommended by Arnon, (1949) for chl. and Horváth et al. (1972) for carotenoids as adopted by Kissimon (1999). Chlorophyll concentration was calculated as $\mathrm{mg} \mathrm{g}^{-1}$ dry weight of leaves.

\section{Estimation of total soluble carbohydrates:}

Carbohydrate extraction and clarification of plant materials (root and shoot) was performed according to Naguib et al. (1968). Total soluble carbohydrates content was estimated by the phenol sulphuric acid method described by Dubois et al. (1956) and Krishnaveni et al. (1984). The 
concentration of total soluble carbohydrates content was calculated as $\mathrm{mg} / \mathrm{g}$ dry weight.

\section{Determination of total soluble protein}

Total soluble protein content was determined in borate buffer extract according to the method described by Bradford (1976) using spectrophotometer (Model RAY LIGHT UV-9200). The concentration of total soluble protein content was calculated as $\mu \mathrm{g} \mathrm{g}^{-1}$ dry weight.

\section{Quantitative estimation of total phenolic compounds}

Extraction of total phenolic compounds was carried out according to Velioglu et al. (1998) and aqueous methanol extract of total phenolic compounds was determined according to the Folin Ciocalteu's method using spectrophotometer (Model RAY LIGHT UV- 9200). A standard curve was prepared using different concentrations of gallic acid and results were expressed as $\mathrm{mg} \mathrm{g}^{-1}$ dry weight.

\section{Statistical analysis:}

The obtained results were statistically analyzed using one way of variance (ANOVA) and LSD was determined at 0.05 level. All statistical methods used in this study were according to Bishop (1983), while the analysis was carried out by SPSS statistical package.

\section{Results}

Nano particles were analyzed using different techniques to determine their physical nature. Thermogravimeteric analysis (TGA) showed two weight losses from 375 to $480{ }^{\circ} \mathrm{C}$ and 480 to $650{ }^{\circ} \mathrm{C}$ (Figure 1). These losses of weight were due to the decomposition of $\mathrm{Ca}(\mathrm{OH})_{2}$ to $\mathrm{CaO}$ and the decomposition of $\mathrm{CaCO}_{3}$ to $\mathrm{CaO}$, respectively.

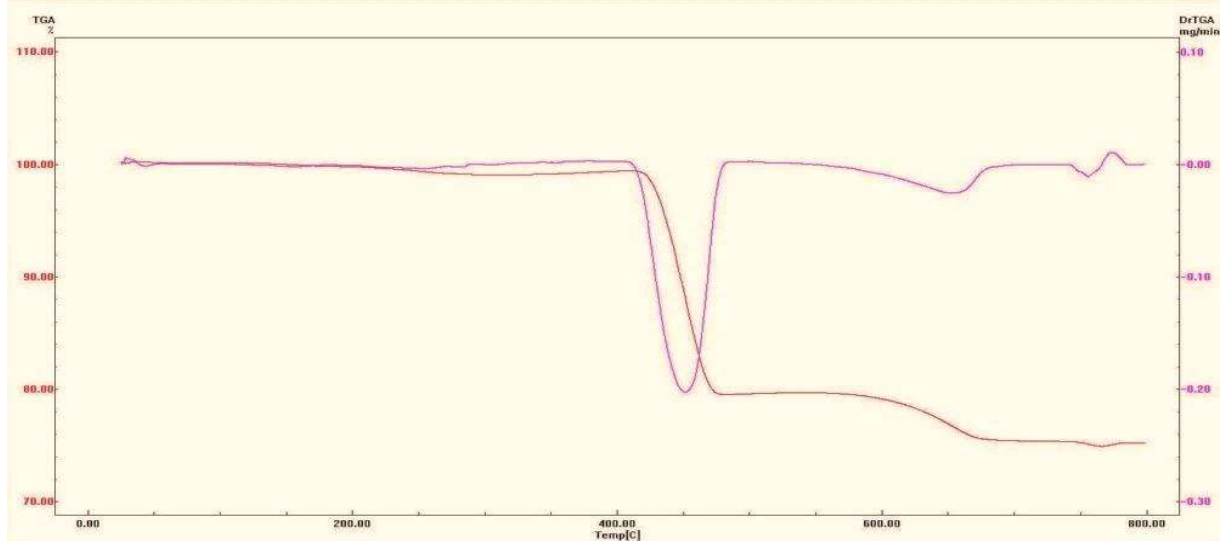

Figure1. TGA curves of the $\mathrm{Ca}(\mathrm{OH})_{2}$ nano-particles from 25 to $800^{\circ} \mathrm{C}$.

$\mathrm{X}$-ray diffraction $(\mathrm{XRD})$ analysis revealed the crystalline nature and the size of both nano calcium (Figure 2). The distinct diffraction peaks at $2 \theta$ values of crystalline $\mathrm{Ca}(\mathrm{OH})_{2}$ and $\mathrm{CaO}$ were 3 peaks. The $2 \theta$ values of the strongest three peaks of crystalline $\mathrm{Ca}(\mathrm{OH})_{2}$ were $18.14,37.19$ and $47.20^{\circ}$, whereas the $2 \theta$ values of the strongest three peaks of crystalline $\mathrm{CaO}$ were 18.09 ,
34.17 and $37.46^{\circ}$. The average crystallite size of $\mathrm{Ca}(\mathrm{OH})_{2}$ and $\mathrm{CaO}$ nano-particles were calculated using Scherrer's equation (Eq. 3) to be about 73 and $91 \mathrm{~nm}$ for $\mathrm{Ca}(\mathrm{OH})_{2}$ and $\mathrm{CaO}$, respectively .

$\mathrm{D}=\frac{0.9 \lambda}{\beta \cos \theta}$

Where $D$ is the mean crystalline size $(\mathrm{nm}), \lambda$ is the wavelength of $\mathrm{Cu} \mathrm{K} \alpha(0.154 \mathrm{~nm}), \beta$ is the full width at 
half maximum intensity (FWHM) in radian and $\theta$ is the

Bragg angle $\left(^{\circ}\right)$.
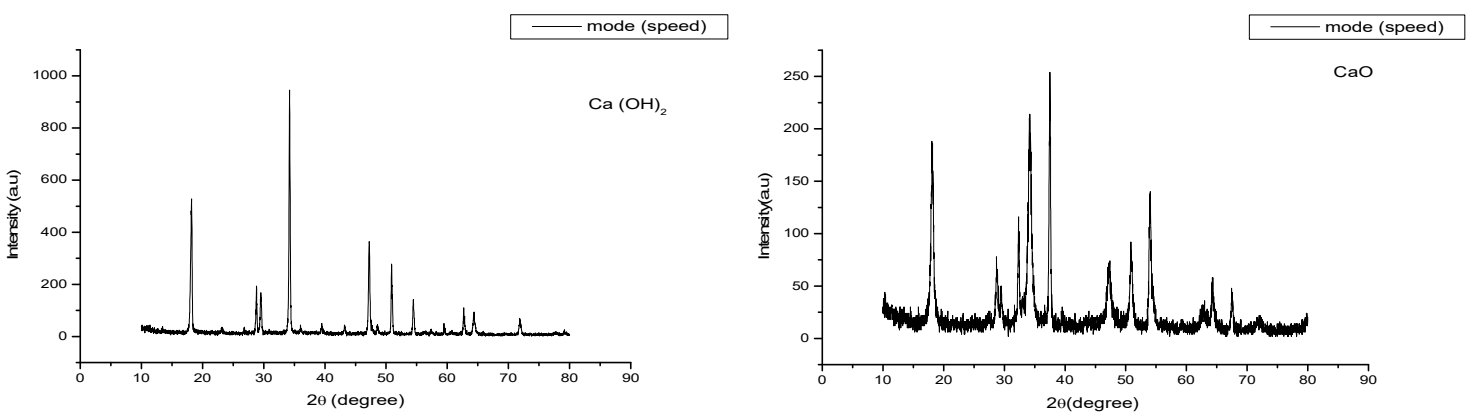

Figure 2. X-ray patterns of $\mathrm{Ca}(\mathrm{OH})_{2}$ and $\mathrm{CaO}$ nanoparticles

The transmission electron microscope (TEM) micrograph of $\mathrm{Ca}(\mathrm{OH})_{2}$ and $\mathrm{CaO}$ describe the nano particles structure (Figure 3). Through the TEM, nano $\mathrm{Ca}(\mathrm{OH})_{2}$ and $\mathrm{CaO}$ had hexagonal and spherical shapes, respectively. The difference between XRD and TEM is that XRD shows the crystalline size of particles, while TEM shows their grain size of particles.
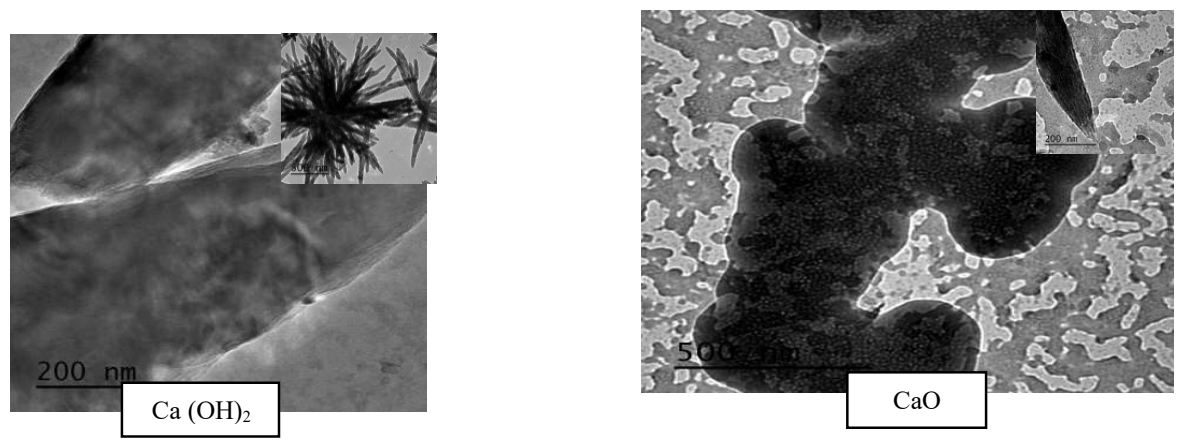

Figure 3. TEM image and distribution of $\mathrm{Ca}(\mathrm{OH})_{2}$ and $\mathrm{CaO}$ nanoparticles

Regarding the effect of different concentrations of both nano $\mathrm{Ca}(\mathrm{OH})_{2}$ and $\mathrm{CaO}$ and bulk $\mathrm{CaCO}_{3}$, the results indicated that all treatments decreased the seedling root length in comparison with the control (Figure 4). The decrease was attained by bulk $\mathrm{CaCO}_{3}$ treatment. $\mathrm{Nano} \mathrm{Ca}(\mathrm{OH})_{2}$ induced the least decrease in root length reaching 26.8, 47.9 and $0.43 \%$ respectively at concentrations of $0.5,1.0$ and $2 \mathrm{mM}$. The shoot length was not significantly affected by increasing nano $\mathrm{Ca}(\mathrm{OH})_{2}$ concentrations. The greatest decrease by nano $\mathrm{CaO}$ in root and shoot lengths was at
$2 \mathrm{mM}$ reaching 52.5 and $11.1 \%$, respectively in root and shoot lengths. On the contrary 0.5 and $1.0 \mathrm{mM}$ nano $\mathrm{CaO}$ significantly increased shoot length relative to the control. Increasing concentration of bulk $\mathrm{CaCO}_{3}$ attenuated the decrease in root and shoot length and slightly increased shoot length at $2 \mathrm{~m}$.

The results in Figure 4 indicated that with nano $\mathrm{Ca}(\mathrm{OH})_{2}$ there was a marked decrease in root fresh weight amounting to $46.3 \%$ at $1.0 \mathrm{mM}$ compared with the control, whereas root dry weight was slightly increased by increasing concentration of nano 
$\mathrm{Ca}(\mathrm{OH})_{2}$, with the exception of $11.5 \%$ decline at 1.0 $\mathrm{mM}$ nano $\mathrm{Ca}(\mathrm{OH})_{2}$ treatment. It is clear that nano $\mathrm{Ca}(\mathrm{OH})_{2}$ markedly increased both shoot fresh and dry weights by 34.0 and $29.0 \%$ respectively at its highest concentration $(2.0 \mathrm{mM})$ compared with the control.

Application of nano $\mathrm{CaO}$ at concentrations of 0.5 and $1.0 \mathrm{mM}$ high significant increased both root and shoot fresh and dry weights, but $2.0 \mathrm{mM}$ nano $\mathrm{CaO}$ decreased both root and shoot fresh and dry weights relative to the control.
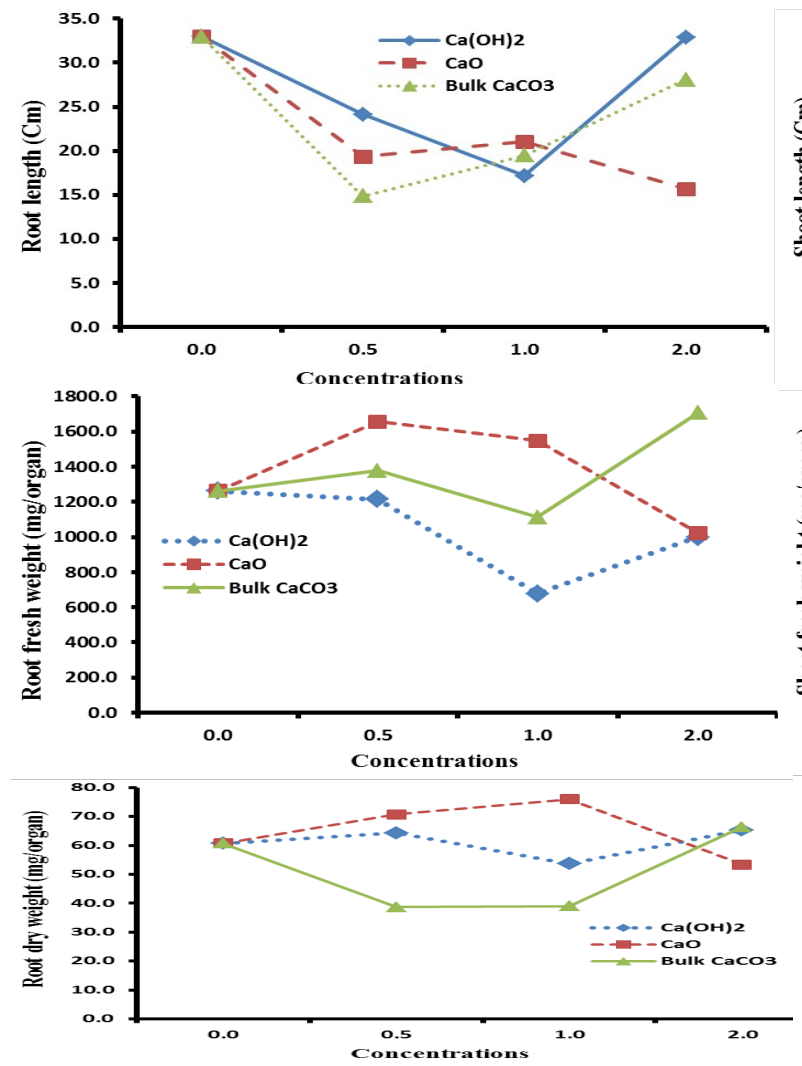
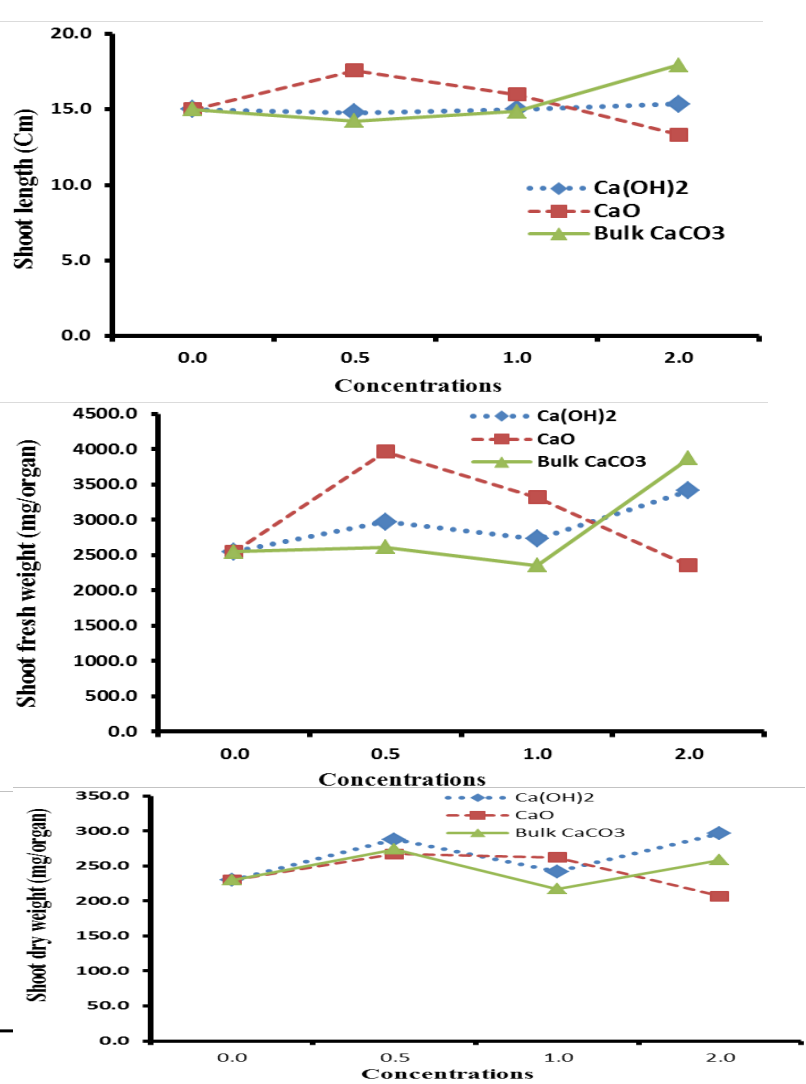

On the other hand, 0.5 and $2.0 \mathrm{mM}$ bulk $\mathrm{CaCO}_{3}$ increased both root and shoot fresh weights compared to the control. Root dry weight was gradually decreased by increasing concentration of bulk $\mathrm{CaCO}_{3}$, with the exception of a slight increase in its

dry weight by $2 \mathrm{mM}$ bulk $\mathrm{CaCO}_{3}$ in comparison with the control. Shoot dry weight increased by bulk $\mathrm{CaCO}_{3}$ at 0.5 and $2 \mathrm{mM}$, whereas it decreased at $1.0 \mathrm{mM}$ $\mathrm{CaCO}_{3}$ treatment compared to control.

Figure 4. Effect of different concentrations of nano calcium either $\mathrm{Ca}(\mathrm{OH})_{2}$ or $\mathrm{CaO}$ and bulk $\mathrm{CaCO}_{3}(\mathrm{mM})$ on length $(\mathrm{cm})$ and both fresh and dry weights (mg/organ) of root and shoot of

\section{Lupinus termis seedling.}

Application of both nano $\mathrm{Ca}(\mathrm{OH})_{2}$ and $\mathrm{CaO}$ and bulk $\mathrm{CaCO}_{3}$ induced pronounced increase in chlorophyll a, chlorophyll b and carotenoids with increasing their concentrations compared to control 
was $152.4,139,4$ and $167.3 \%$, respectively and by bulk $\mathrm{CaCO}_{3}$ it reached $113.8,118.7$ and $92.2 \%$, respectively compared with the control. This indicated that pigment biosynthesis was greatest by nano $\mathrm{Ca}(\mathrm{OH})_{2}$ compared to their nano $\mathrm{CaO}$ or bulk $\mathrm{CaCO}_{3}$.
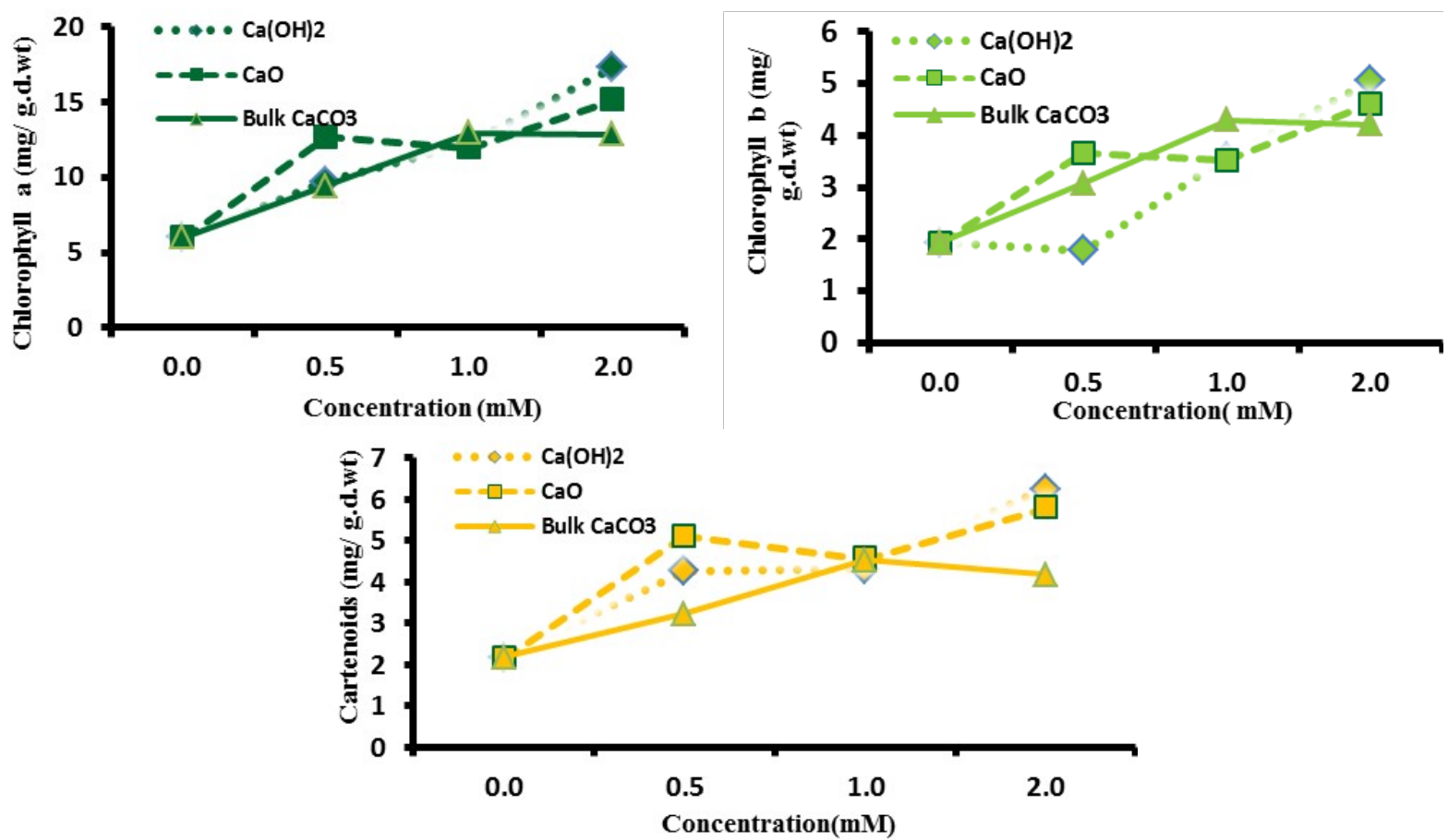

Figure 5. Effect of different concentrations of nano calcium either $\mathrm{Ca}(\mathrm{OH})_{2}$ or $\mathrm{CaO}$ and bulk $\mathrm{CaCO}_{3}(\mathrm{mM})$ on photosynthetic pigments (mg/g d.wt.) of Lupinus termis seedling.

Generally the content of total soluble carbohydrates tended to decrease in root and shoot parallely to the increase in the concentration of both nano $\mathrm{Ca}(\mathrm{OH})_{2}$ and $\mathrm{CaO}$ except for $2 \mathrm{mM}$ nano $\mathrm{CaO}$ which increased root total soluble carbohydrates by $46.4 \%$ relative to control (Figure 6). The content of total soluble carbohydrates was gradually decreased in root by increasing the concentration of bulk $\mathrm{CaCO}_{3}$, while it was increased in shoot reaching to $53.2 \%$ at $1.0 \mathrm{mM}$ $\mathrm{CaCO} 3$ compared with the control.

It is evident from data in Figure 6 that total soluble protein content was decreased in root and shoot parallely to the increase in the concentration of both nano $\mathrm{Ca}(\mathrm{OH})_{2}$ and $\mathrm{CaO}$ and bulk $\mathrm{CaCO}_{3}$ with the exception of the shoot total soluble protein which was increased with nano $\mathrm{Ca}(\mathrm{OH})_{2}$ at 1.0 and $2.0 \mathrm{mM}$ compared with the control. The percentage of increase in the content of shoot total soluble protein at 1.0 and $2.0 \mathrm{mM}$ nano $\mathrm{Ca}(\mathrm{OH})_{2}$ was 5.8 and $23 \%$, orderly compared with the control. 

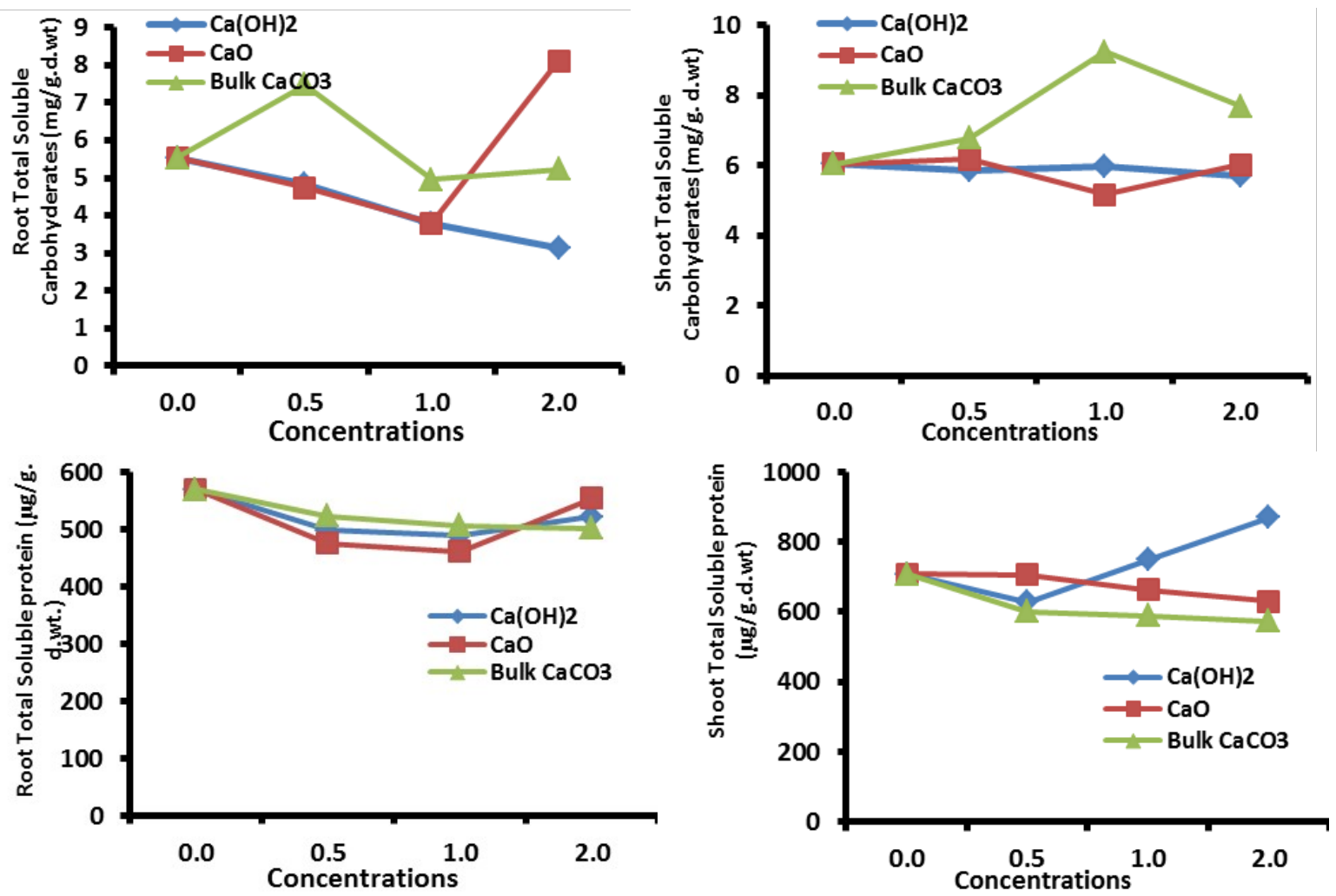

Figure 6. Effect of different concentrations of nano calcium either $\mathrm{Ca}(\mathrm{OH})_{2}$ or $\mathrm{CaO}$ and bulk $\mathrm{CaCO}_{3}(\mathrm{mM})$ on both root and shoot total soluble carbohydrates and proteins content $(\mathrm{mg} / \mathrm{g} \mathrm{d}$.

wt.) of Lupinus termis seedling.

The data in Figure 7 indicated that the content of root phenolic compounds was gradually decreased with increasing the concentration both nano calcium compounds and bulk $\mathrm{CaCO}_{3}$ compared with the control. The magnitude of decrease was greater by nano compound at $0.5 \mathrm{mM}$ than by the bulk $\mathrm{CaCO}_{3}$, while a reserve situation was observed at 1.0 and $2.0 \mathrm{mM}$.
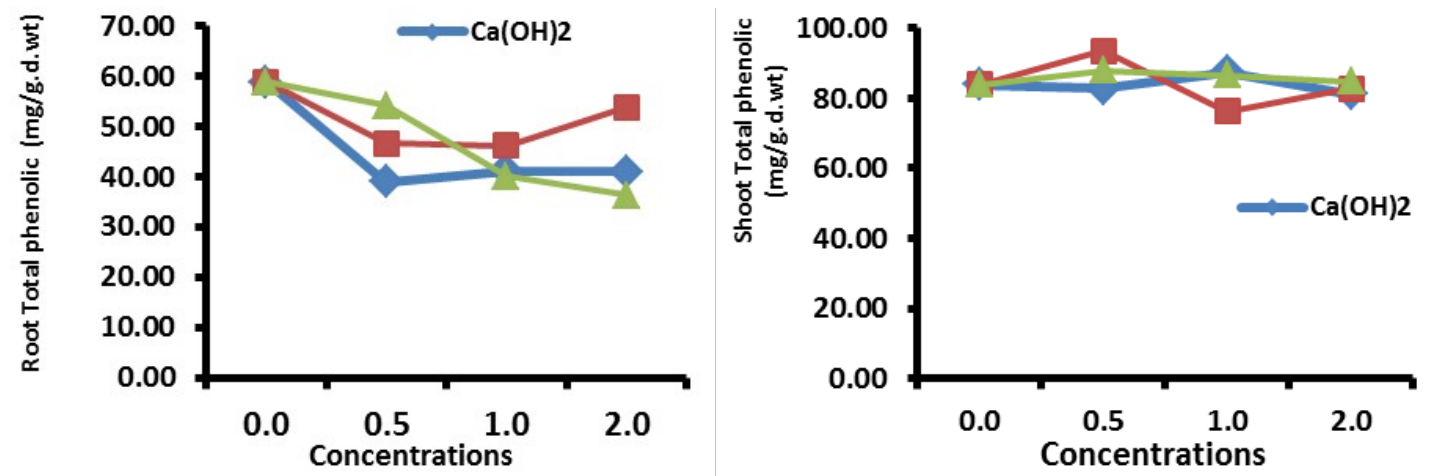
Figure 7. Effect of different concentrations of nano calcium either $\mathrm{Ca}(\mathrm{OH})_{2}$ or $\mathrm{CaO}$ and bulk $\mathrm{CaCO}_{3}(\mathrm{mM})$ on root and shoot total phenolic compounds content (mg/g d. wt.) of Lupinus termis seedling.

\section{Statistical analysis:}

The statistical analysis (Table 1) indicated that different concentrations and forms of calcium applied to Lupines termis seeds led to highly significant variation $(\mathrm{P} \leq 0.01)$ in the seedling growth criteria, photosynthetic pigments and the investigated primary and secondary metabolites.

Table 1. Analysis of variance (ANOVA) for growth criteria, photosynthetic pigments and other metabolites under different concentrations of calcium forms and their interaction.

\begin{tabular}{|c|c|c|c|}
\hline \multirow{2}{*}{ Parameters } & \multicolumn{2}{|c|}{ Calcium } & \multirow{2}{*}{$\begin{array}{c}\text { Interactions } \\
\text { (Concentrations*Forms) }\end{array}$} \\
\hline & Concentrations & Forms & \\
\hline Root length & $90.9^{* *}$ & $15.2^{* *}$ & $19.9^{* *}$ \\
\hline Shoot length & $1.5^{* *}$ & $2.2^{* *}$ & $22.3^{* *}$ \\
\hline Root fresh weight & $5.2^{* *}$ & $16.4^{* *}$ & $9.7^{* *}$ \\
\hline Shoot fresh weight & $22.6^{* *}$ & $3.1^{* *}$ & $31.6^{* *}$ \\
\hline Root dry weight & $6.6^{* *}$ & $22.1^{* *}$ & $17.6^{* *}$ \\
\hline Shoot dry weight & $24.6^{* *}$ & $11.9^{* *}$ & $13.9^{* *}$ \\
\hline Chlorophyll a content & $167219.8^{* *}$ & $6033.7^{* *}$ & $8898.8^{* *}$ \\
\hline Chlorophyll b content & $5432.6^{* *}$ & $183.5^{* *}$ & $502.9^{* *}$ \\
\hline Carotenoids content & $353334.0^{* *}$ & $56973.4^{* *}$ & $25349.6^{* *}$ \\
\hline Root carbohydrate & $16175.2^{* *}$ & $27469.1^{* *}$ & $24144.5^{* *}$ \\
\hline Shoot carbohydrate & $4592.9^{* *}$ & $49311.5^{* *}$ & $13749.8^{* *}$ \\
\hline Root protein & $1972.9^{* *}$ & $48.9^{* *}$ & $272.8^{* *}$ \\
\hline Shoot protein & $4282.3^{* *}$ & $27619.0^{* *}$ & $12397.2^{* *}$ \\
\hline Root total phenolic & $322258.1^{* *}$ & $12.7^{* *}$ & $11.2^{* *}$ \\
\hline Shoot total phenolic & $2973939.6^{* *}$ & $12.1^{* *}$ & $57.0^{* *}$ \\
\hline
\end{tabular}

${ }^{*}$ Significant at $\mathrm{P} \leq \mathbf{0 . 0 5}{ }^{* *}$ highly significant at $\mathrm{P} \leq \mathbf{0 . 0 1}$

\section{Discussion}

Very rare literatures were found about using nano calcium for improving plant growth and production (Liu et al., 2005). Results of the present study showed that calcium in the nano forms was superior in its effects compared with the control. However, both root and shoot lengths of Lupinus termis seedligs were significantly decreased with increasing all calcium treatments from ( 0.5 to $2.0 \mathrm{mM})$.
These results agreed with those of Yin et al. (2011) who showed that Ag nanoparticles (AgNPs) has affected the root elongation and root growth of eleven wetland plants at very low concentrations. The present results are also in accordance with those obtained by Yasur and Usha Rani (2013) who found that using AgNPs (500- $4000 \mathrm{mg} / \mathrm{l})$ did not affect shoot elongation patterns in the castor germinated seedlings. In addition, Yugandhar and Savithramma 
showed that shoot length of Vigna mungo was increased by the application of $\mathrm{CaCO}_{3}$ nanoparticles. On the contrary, treatment of Bacopa monnieri by bulk $\mathrm{AgNO}_{3}$ exhibited a marked retardation with increasing concentration (Krishnaraj et al., 2012). In the present study, the significant increase in both shoot fresh and dry weights at $2 \mathrm{mM}$ nano $\mathrm{Ca}(\mathrm{OH})_{2}$ and 0.5 and 1.0 $\mathrm{mM}$ nano $\mathrm{CaO}$ was in agreement with results of Yugandhar and Savithramma (2013) who reported that shoot fresh and dry weights of Vigna mungo were increased by $\mathrm{CaCO}_{3}$ nanoparticles as well as by $10 \mathrm{mM}$ $\mathrm{CaCl}_{2}$. In addition, $\mathrm{TiO}_{2}$ nanoparticles were found to promote growth action of spinach (Yang et al., 2006).

Application of high concentrations of both nano $\mathrm{Ca}(\mathrm{OH})_{2}$ and $\mathrm{CaO}$ and bulk $\mathrm{CaCO}_{3}$ induced pronounced increases in chlorophyll a, chlorophyll b and carotenoids relative to control. These results were in accordance with those obtained by Morteza (2013) and Tantawy et al. (2014) on Zea mays and tomato plants respectively. They reported that the content of chlorophyll (chl.a and chl.b) and carotenoids was significantly increased under nano $\mathrm{TiO}_{2}$ spraying on the first plant and increased total chlorophyll content under 0.5 and $1.0 \mathrm{~g} / 1$ nano calcium carbonate in the second one.

Total soluble carbohydrates content in root and shoot was significantly decreased by either nano calcium or $\mathrm{CaCO}_{3}$. This result was consistant with that of Krishnaraj et al. (2012) who found that carbohydrates content of root and leaf of Bacopa monnieri were dropped in levels during subsequent exposure to nano silver and bulk silver nitrate. The concomitant increase in carbohydrates content in shoot with the decrease in root may indicate their translocation.

The results indicated that total soluble protein content was decreased in root and shoot parallely to the increase in concentration of both nano $\mathrm{Ca}(\mathrm{OH})_{2}$ and $\mathrm{CaO}$ and bulk $\mathrm{CaCO}_{3}$ s. These results agreed with those of Krishnaraj et al. (2012) who reported that the protein content in different organs of Bacopa monnieri plants treated with AgNPs was lower than that the of control

Changes in total soluble carbohydrates and protein may be attributed to changes in processes associated with photosystems, starch synthesizing machineries and/or carbohydrates translocation as postulated by Krishnaraj et al. (2012).

The biological molecules such as secondary metabolites could possibly play a major role in the synthesis and stabilization of the nanoparticles (Inbakandan et al., 2010). In the present study, increased total phenolic compounds in the seedlings produced from seeds treated with both nano $\mathrm{Ca}(\mathrm{OH})_{2}$ and $\mathrm{CaO}$ and bulk $\mathrm{CaCO}_{3}$ showed a shift towards secondary metabolism. The content of root phenolic compounds was gradually decreased with increasing concentration of both nano calcium and bulk $\mathrm{CaCO}_{3}$ compared with control. This result was consistent with Yasur and Usha Rani (2013) who found that the content of total phenolic compounds was decreased at $2000 \mathrm{mg} / 1$ of AgNPs in castor seedlings compared with control and all other treatments. The increase in the content of shoot phenolic compounds by $1 \mathrm{mM}$ of nano $\mathrm{Ca}(\mathrm{OH})_{2}$ and by $0.5 \mathrm{mM}$ nano $\mathrm{CaO}$ and bulk $\mathrm{CaCO}_{3}$ may be referred to shoot allocation for such compounds rather than translocation to root.This was in harmony with the finding of Krishnaraj et al. (2012) who found that the total phenolic compounds in the leaves of Bacopa monnieri was increased by both forms of silver (AgNPs and $\mathrm{AgNO}_{3}$ ).

It can be concluded that using calcium nanoparticles in the form of either $\mathrm{Ca}(\mathrm{OH})_{2}$ or $\mathrm{CaO}$ is more beneficial for improvement of plant growth than using it as bulk $\mathrm{CaCO}_{3}$.

\section{REFERENCES}

Arnon, D.I. (1949). Copper enzymes in isolated chloroplasts, polyphenoxidase in beta vulgaris. Plant Physiol., 24, 1-15. 
ASTM (2006). International Standard E2456-06, Standard Terminology Relating to Nanotechnology. (pdf available at http://www.astm.org/cgibin/SoftCart.exe/DATABASE.CART/REDLI NE_PAGES/E2456.htm?L+mystore+sfjz7039 ; accessed 4 Dec 2006).

Bhardwaj, H. L.; Starner, D. E. and Van Santen, E. (2010). Preliminary evaluation of white lupin (Lupinus albus L.) as forage crop in the midatlantic region of the United State of America. Agric. Sci., 2, 13-17.

Bishop, O. N. (1983). Statistics in Biology. Longman, Penguin, London., 56-63.

Bradford, M.M. (1976). A rapid and sensitive method for the quantification of microgram quantities of protein utilizing the principle of protein dye binding. Anal Biochem 72, 248-254

Chango, A.; Villaume, C.; Bau, H.M.; Schwertz, A.; Nicolas, J. and Mejean, L. (1998). Effects of casein, sweet lupin and sweet yellow lupin diet on cholesterol metabolism in rats. Sci. Food Agric. 76, 301-309.

Chiej R. (1984). The Macdonald Encyclopedia of Medicinal Plants. Macdonald \& Co. (Publishers) Ltd., Maxwell House, London. 447 pp.

Dubois, M.; Gilles, K.A.; Hamilton, J.K.; Rebers. P.A. and Smith, F. (1956). Colorimetric method for determination of sugars and related substances. Anal. Chem., 28, 350-356.

EFSA., (2005). Opinion of the scientific panel on dietetic products, nutrition and allergies on a request from the commission related to the evaluation of lupin for labelling purposes. EFSA J., 302, 1-11.

Erbas, M.; Certel, M. and Uslu,M.K. (2005). Some chemical properties of white lupin seeds (Lupinus albus L.). Food Chem., 89, 341-345.
Gabrial, G.N. and Morcos, S.R. (1976). The use of Lupinus termis L. cultivated in Egypt, as a food protein supplement. Z. Ernährungswlss. 15, 333-339.

Getachew, P. (2009). Chemical composition and the effects of traditional processing on nutritional composition of gibto (Lupinus albus L.) grown in, Gojam area. M.Sc. Thesis, Addis Ababa University, Addis Ababa, Ethiopia.

Gladstones, J.S. (1998). Distribution, origin, taxonomy, history and importance. Chapter 1. In: J.S. Gladstones, C. Atkins, J. Hamblin (Eds.), Lupins as Crop Plants: Biology, Production and Utilization, CAB International, New York, USA, pp. 1-39

Horváth, G.; Kissimon, J. and Faludi-Dániel, Á. (1972). Effect of light intensity on the formation of carotenoids in normal and mutant maize leaves. Phytochem., 11, 183-187.

Huyghe, C. (1997). White lupin (Lupinus albus L.). Field Crops Res., 53, 147-160.

Inbakandan., Venkatesan. and Ajmal Khan. (2010). Biosynthesis of gold nanoparticles utilizing marine sponge Acanthella elongata (Dendy, 1905), Colloids and Surfaces B: Biointerfaces., 81(2), 634-639.

Kettel, K., B.; Tuck, W.A.; Payne, C.; Chen, S. M. and Karow R., (2003). Narrow-leaf lupin. Dryland Cropping Systems, Oregon State University Extension Service. http://ir.library.oregonstate.edu/xmlui/handle/ $1957 / 20321$.

Kissimon, J. (1999). Analysis of the photosynthetic pigment composition. Proceedings of the International Workshop and Training Course on Microalgal Biol. and Biotech. Mosonmagyar, Hungary. 13-26.

Krishnaraj, C.; Jagan, E.G.; Ramachandran, R.; Abirami, S.M.; Mohan, N. and Kalaichelvan, P.T. (2012). Effect of biologically synthesized 
silver nanoparticles on Bacopa monnieri

(Linn.) Process Biochem., 47, 651-658

Krishnaveni, S.; Theymoli B. and Sadasivam, S. (1984). Phenol sulphuric acid method. Food Chem., 15, 229.

Kwak, B.O.; Kim, H.J. and Park H.S. (2000). The effect of different lupin kernel inclusion levels on the growth and carcass composition of growing and finishing pigs. Asian-Aust. Anim. Sci., 13, 207-212.

Liu, X.; Zhang, F.; Zhang, S.; He, X.; Wang, R.; Feng, Z. and Wang, Y. (2005). Responses of peanut to nano calcium carbonate. Plant nutrition and fertilizer science. 11(3), 385-389.

Loza, A. and Lampart-Szczapa, E. (2008). Allergenicity of lupin proteins - a review. Polish Food Nutr. Sci. 58, 283-287.

Mirghiasi, Z.; Fereshteh, B.; Esmaeel, D. and Esmat E. (2014). Preparation and characterization of $\mathrm{CaO}$ nanoparticles from $\mathrm{Ca}(\mathrm{OH})_{2}$ by direct thermal decomposition method. J. Indust. and Engin. Chem. 20, 113-117.

Morteza, E.; Moaveni, P.; Aliabadi Farahani, H. and Kiyani, M. (2013). Study of photosynthetic pigments changes of maize (Zea mays L.) under nano $\mathrm{TiO}_{2}$ spraying at various growth stages. Springer Plus, 2, 247-251.

Naguib, M.I.; Youssef, E. and Kinawy, M.M. (1968). Effect of kinetin on the nitrogen metabolism of radish plants. Bull. Fac. Sci. Cairo Univ., $42,13-22$

Olver, M.D., (1998). Effects of sweet, bitter and soaked micronised bitter lupins on duckling performance. Br. Poult. Sci., 39, 622-626.

Oskam, G. (2006). Metal oxide nanoparticles: synthesis, characterization and application. Sol-Gel Sci. Technol. 37, 161-164.

Peralta-Videa, J.R.; Zhao, L.; Lopez-Moreno, M.L.; de la Rosa, G.; Hong, J. and Gardea- Torresdey, J.L. (2011). Nanomaterials and the environment: a review for the biennium 20082010. J. Hazar. Mat. 186, 1-15.

Petterson ,D.S. (1998). Composition and food uses of lupins. In: Gladstones JS, Atkins C, Hamblin J (eds) Lupins as crop plants. Biology: production and utilization. CABI, Oxon, 353384.

Rao, S. and Shekhawat, G.S. (2014). Toxicity of ZnO Engineered Nanoparticles and Evaluation of Their Effect on Growth, Metabolism and Tissue Specific Accumulation in Brassica juncea. Environ. Chem.Engin.2, 105-114.

Ruffini Castiglione, M. and Cremonini, R. (2009). NPs and higher plants. Caryol. 62,161-165

Savithramma, N. (2002). Influence of calcium supply on biomass production of endemic and endangered tree species of tirumala hills of south Eastern Ghats. Indian Botani. Soci., 81,323-326

Savithramma, N. (2004). Influence of calcium supply on photosynthetic rate in relation to calmodulin in endemic and endangered tree saplings of seshachlam hills of South Eastern Ghats of India. Indian Plant Biol., 31(3), 1-6.

Savithramma, N.; Fareeda, G.; Madhavi, V. and Murthy, S.S.D. (2007). Effect of calcium on photochemical activities of green leafy vegetables. Plant Biology. 34 (2), 95-98.

Tantawy, A.S.; Salama, Y. A. M.; Abdel-Mawgoud, A.M.R. and Ghoname, A.A. (2014). Comparison of Chelated Calcium with Nano Calcium on Alleviation of Salinity Negative Effects on Tomato Plants. Middle East Journal of Agriculture Research, 3(4), 912-916.

Velioglu, Y.S.; Mazza, G.; Gao, L. and Oomah, B.D. (1998). Antioxidant activity and total phenolics in selected fruits, vegetables and grain products. Agric. Food Chem. 46, 41134117. 
Yang, F.; Hong, F.; You, W.; Liu, C.; Gao, F.; Wu, C. and Yang, P. (2006). Influences of nanoanatase $\mathrm{TiO}_{2}$ on the nitrogen metabolism of growing spinach. Biological Trace Element Res., 110, 179-190.

Yasur, J. and Usha Rani, P. (2013). Environmental effects of nanosilver: impact on castor seed germination, seedling growth, and plant physiology. Environmental Science and Pollution Research. 20 (12), 8636-8648.

Yeheyis, L.; C. Kijora, Wink, M. and Peters, K.J. (2011). Effect of a traditional processing method on the chemical composition of local white lupin (Lupinus albus L.) seed in North-
Western Ethiopia. Z. Naturforsch. C, 66,403408.

Yildiz, S., (2011). Rotational and nematicidal effect of lupine (Lupinus albus L.: Leguminosae). Afr. Biotechnol., 10, 13252-13255.

Yin, L.; Cheng, Y.; Colman, B.P.; Auffan, M.; Wiesner, M.; Rose. J.; Liu, J. and Bernhardt, E.S. (2011). More than the ions: The effect of silver nano particles on Lolium multiflorum. Environ. Sci. and Technol., 45, 2360-2367.

Yugandhar, P. and Savithramma, N. (2013). Green synthesis of calcium carbonate nanoparticles and their effects on seed germination and seedling growth of Vigna mungo (L.). Hepper. Inter. Advanced Res. 1(8), 89-103. 
تأثير نانو هيدروكسيد وأكسيد الكالسيوم على بعض الأثثطة الأيضية والمركبات الفينوليه لبادرات نبات الترمس

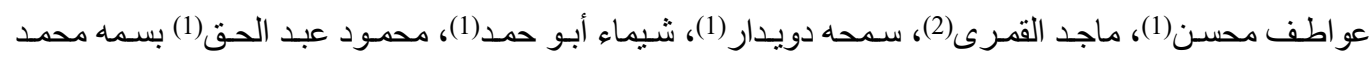

خلف(1)

(1) ق قسم النباتـ كلية العلوم- جامعة طنطا

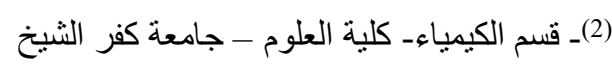

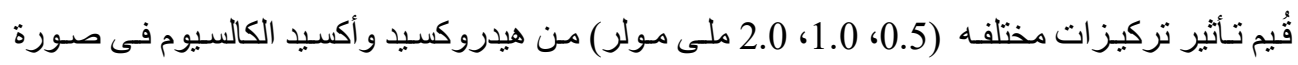

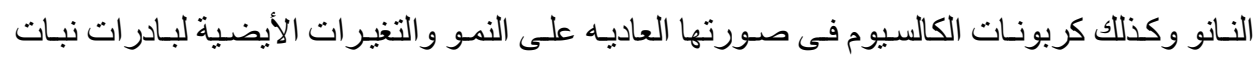

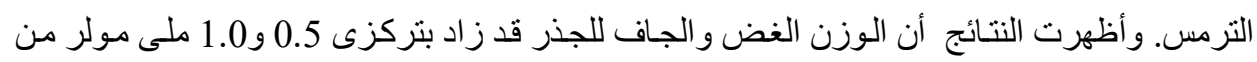
نانو أكسيد الكالسيوم مقارنه بـالكنترول، بينمـا كلَ من الوزن الغض و الجـاف للجذر قد نقص مـع زيادة

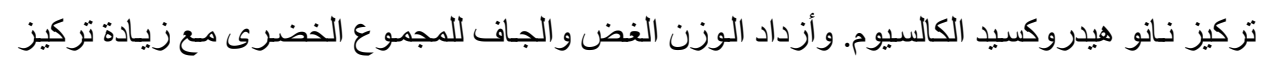

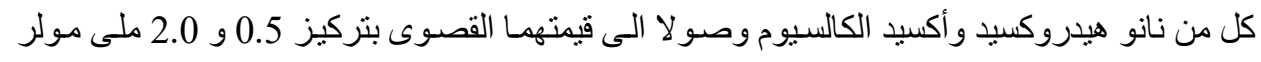

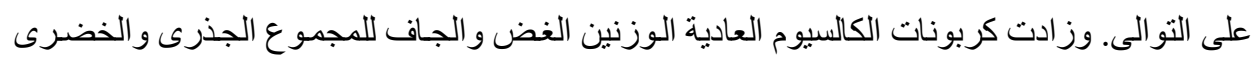
عند أعلى تركيز لها (2.0 ملى مولر ). وكان هناك زياده ملحوظه فى أصباغ البناء الضونئى (كلوروفيل ا، كلوروفيل ب و الكاروتنينيدات) بزيادة تركيز نانو هيدروكسيد وأكسيد الكالسيوم وكربونات الكالسيوم

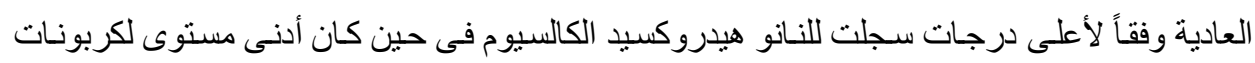

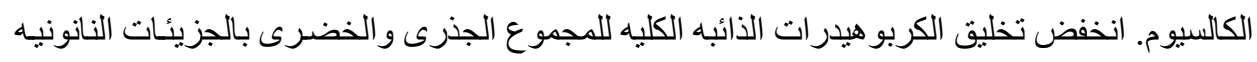

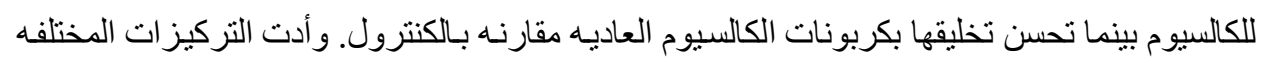

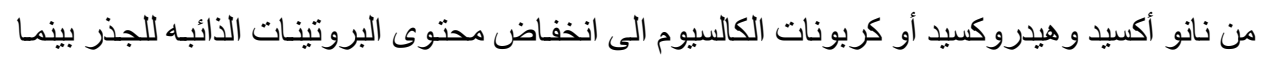
ازداد محتو ها فى الهموع الخضرى بكل أنكال الكالسيوم مقارنة بالكنترول. نـانو كالسيوم خاصـة نـانو

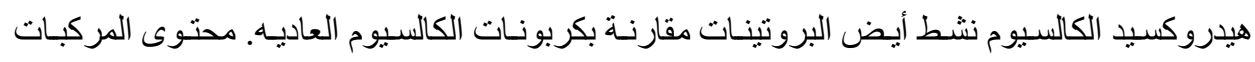

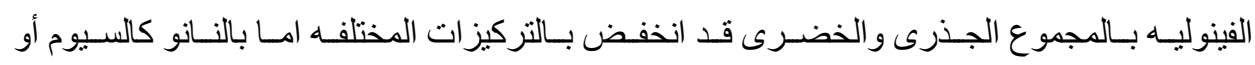
بكربونات الكالسيوم العاديه بإستثناء محتوى المركبات الفينوليه للمجموع الخضرى المعامله بكربونـات الكالسيوم العاديه ـ وقد ازدات المركبات الفينوليه للمجموع الخضرى بنسبة 10\% عند نركيز 0.5 ملى لهى مولر من نانو أكسيد الكالسيو مقارنة بالكنترول. 